\title{
CLEC10A wt Allele
}

National Cancer Institute

\section{Source}

National Cancer Institute. CLEC10A wt Allele. NCI Thesaurus. Code C122765.

Human CLEC10A wild-type allele is located in the vicinity of 17p13.1 and is approximately $6 \mathrm{~kb}$ in length. This allele, which encodes C-type lectin domain family 10 member A protein, plays a role in regulating innate and adaptive immune responses. 